PRZEGLĄD RUSYCYSTYCZNY 2020, nr 2(170)

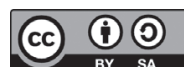

DOI 10.31261/pr.7764

PIOTR ZEMSZAŁ

Uniwersytet Mikołaja Kopernika w Toruniu

(D) ORCID: 0000-0002-0822-8937

\title{
WIZERUNEK WŁADIMIRA MAJAKOWSKIEGO W SOWIECKIEJ PROPAGANDZIE KULTURALNEJ W LATACH 1953-1957
}

\section{THE IMAGE OF VLADIMIR MAYAKOVSKY \\ IN THE SOVIET CULTURAL PROPAGANDA IN A PERIOD OF 1953-1957.}

The paper concerns components of Vladimir Mayakovsky's image useful in the Soviet cultural propaganda during the first stag after Joseph Stalin's death. Exceptionally popular already during his lifetime, after his death the poet was considered a father of the literature of the new Communist world, besides Maxim Gorky, and the greatest amongst the Soviet poets. The research material consists of articles about the culture published in the newspaper 'Pravda' in 1953-1957. About 2\% of them concerned Mayakovsky. This high percentage rate, taking into account that they concerned a single poet against a background of the entire cultural, and not only literary, life of the Soviet Union, results from the fact that this person "served" simultaneously several fields of interest, where "the old" opposed "the new." Mayakovsky was an embodiment of a specifically understood "citizenship" and commitment, which was set against the lack of any ideology in trends from outside of the Socialist realism stream, he was also an epitome of the fight itself and, finally, a personified negation of the thesis about the rigidity and stuffiness of the Socialist realism.

Keywords: Mayakovski, propaganda, soviet ideological discourse

\author{
А мы \\ не деревообделочники разве? \\ Голов люских обделываем дубы. \\ (В. Маяковский, Поэт рабочий)
}

Powyższy cytat z wiersza Władimira Majakowskiego wskazuje na jego świadomość roli literatury w aparacie służącym tworzeniu komunistycznego „nowego człowieka”. Pisząc jednak te słowa, prawdo- 
podobnie nie zdawał sobie sprawy z tego, że nie tylko jego hasła propagandowe, wiersze i poematy, ale również sama jego postać stanie się narzędziem tego aparatu. Niezwykle popularny jeszcze za życia poeta po śmierci został uznany, obok Maksyma Gorkiego, za jednego z ojców literatury nowego, komunistycznego świata, i najważniejszego spośród poetów radzieckich. Nie był to bynajmniej wzlot krótkotrwały, jakie zdarzają się w totalitaryzmach i autorytaryzmach, kiedy po okresie świetności wraz z upadkiem danej formacji ideologicznej w niebyt odchodzi również większość jej piewców. Majakowski nadal uważany jest za wielkiego poetę, a nawet za poetę aktualnego. Jak pisze Dymitrij Bykow:

Как бы то ни было, Маяковский со всеми его ужасами для нас сегодня - недосягаемый идеал, мечта, знамя прогресса в эпоху тотального, пышно цветущего регресса. Нельзя было не отторгать его во времена искусственного насаждения, при сталинской власти; нельзя было не отозваться ему в шестидесятые, когда выросло наконец вымечтанное им поколение идеалистов и «большелобых химиков»; в семидесятые он выглядел анахронизмом и напоминал об еще одной несбывшейся утопии, а начиная с девяностых, когда потребность в утопии сделалась всеобщей, - постепенно возвращается и сегодня опять говорит как живой с живыми. Весьма возможно, что Маяковский - по крайней мере, кроме двух или трех лирических поэм годится только для эпох, когда надо взрывать ледяную пустыню, выжигать гниль, делать над собой сверхчеловеческое усилие; допускаю даже, что для жизни как таковой - всегда более сложной, богатой и противоречивой, нежели борьба и сплошное созидание, - он не годится вовсе. Но мало какой поэт может похвастаться универсальностью: Блок, например, в некоторые эпохи вовсе не понятен. Маяковский необходим тогда, когда надо прыгнуть выше головы. Сегодня мы должны сделать именно это, потому что падать дальше некуда. Так что сегодня он поэт номер один, даже если кто этого еще и не понял ${ }^{1}$.

Majakowski stał się wzorem poety epoki stalinowskiej, walczącego poety - rewolucjonisty, który swój talent oddał na służbę nowej cywilizacji. Dyskurs okresu stalinowskiego, poza oczywistym kultem wodza, stworzył wielu innych idoli, których zadaniem miało być wskazywanie drogi reprezentantom różnych środowisk. Dla robotników był to Aleksiej Stachanow, dla uczonych - Trofim Łysenko, dla lotników - Walerij Czkałow, dla młodzieży - Pawlik Morozow itd. Wzorcem dla prozaików miał być Maksym Gorki, dla poetów - Majakowski. Sam Stalin w notatce adresowanej do Nikołaja Jeżowa pisał w 1935

1 Д.Л. Быков, Маяковский. Трагедия-буфф в шести действиях, Издательство Молодая гвардия, Москва 2016, s. 659-66о. 
roku: „Маяковский был и остается лучшим и талантливейшим поэтом нашей советской эпохи. Безразличие к его памяти и к его произведениям - преступление"2. Poeta po śmierci stał się zatem nie tylko twórcą, niejako podmiotem radzieckiej propagandy, ale również jej przedmiotem, jednym z zadanych jej tematów. Celem poniższego szkicu jest przedstawienie i analiza obrazu poety, jaki wyłania się z tekstów poświęconych Majakowskiemu i jego twórczości u schyłku stalinizmu, tj. w latach 1953-1957. Materiał badawczy został wyekscerpowany z artykułu wstępnego do Dzieł wybranych Majakowskiego (wydanie 1953) autorstwa Wiktora Piercowa ${ }^{3}$ oraz tekstów gazety „Prawda”, w szczególności dotyczących życia i twórczości poety. Co warte podkreślenia, wśród 397 tekstów dotyczących kultury opublikowanych przez gazetę w ciągu badanego pięciolecia aż 8 (czyli nieco ponad 2\%) skupiało się na postaci Majakowskiego i jego twórczości jako głównym temacie. Co prawda, 2\% jako wyraz znaczenia postaci Majakowskiego dla dyskursu kulturalnego na pierwszy rzut oka nie wygląda zbyt przekonująco, ale jeśli uświadomić sobie, że badane teksty dotyczą tak rozległej tematyki, jaką jest ogólnie pojęta kultura (tj. są to m.in. relacje z wydarzeń kulturalnych, recenzje filmów i sztuk teatralnych, programowe teksty powstałe w czasie zjazdów pisarzy, kompozytorów itp., materiały wspomnieniowe dotyczące pisarzy rosyjskich, radzieckich, zagranicznych itd.), to należy ten wynik uznać za imponujący. W wielu tekstach dotyczących literatury Majakowski pojawia się również jako przykład wzorcowego twórcy rewolucyjnego, nie będąc przy tym pierwszoplanowym bohaterem narracji. Zasadne jest pytanie, dlaczego to akurat Majakowski staje się pierwszoplanową postacią oficjalnego dyskursu o literaturze okresu późnego stalinizmu. Odpowiedzi jest zapewne kilka - poeta był płomiennym propagatorem ideologii komunistycznej, twórcą nie tylko zaangażowanym, ale wręcz walczącym o zwycięstwo tej ideologii. Wysunięcie go na pierwszy plan właśnie w okresie schyłkowego stalinizmu miało sens o tyle, że zbliżało się wówczas starcie stalinowskiego paradygmatu kulturalnego z oddolnymi tendencjami odwilżowymi, postać Majakowskiego była zaś idealnym narzędziem mobilizacji do tej walki. Z punktu widzenia propagandy kulturalnej broniącego

2 И.В. Сталин, Сочинения, т. 18, Информационно-издательский центр «Союз», Тверь 2006, s. 115.

3 В.О. Перцов, Великий поэт советской эпохи, w: В. В. Маяковский, Избранные произведения, Государственное издательство художественной литературы, Москва 1953, s. 3-36. 
swoich pozycji stalinizmu fantom Majakowskiego był użyteczny również dlatego, że w nurcie odwilżowym wyraźnie wybrzmiewały zarzuty marazmu, skostnienia, którym można było przeciwstawić Majakowskiego - literackiego nowatora, burzyciela starych kanonów estetycznych. Tych walorów Majakowskiemu jako poecie nie mógł odmówić nawet najbardziej antystalinowsko nastawiony krytyk.

\section{ROLA I POSTAWA POETY}

Na pierwszy plan w narracjach o Majakowskim wysuwa się rola poety w społeczeństwie, którą można określić jako funkcję propagandzisty ideologii komunistycznej, twórcy ze wszech miar zaangażowanego, która wyrażana była za pomocą szeregu nominacji: поэт революции, поэт-трибун (поэт - трибун эпохи социализма), поэт-агитатор, вдохновенный певец коммунистической партии, поэтический глашатай идеи советского патриотизма, поэтгражданин:

(1) Поэт-гражданин страстно призывал к революционной бдительности во имя коренных интересов народа и социалистического государства [I];

(2) Поэт-трибун жил чувствами и мыслями передовых людей своей эпохи... [II, s. 19];

(3) Великий поэт - трибун эпохи социализма, был великим мастером стиха [II, s. 35];

(4) Первый, кого мы видим, - это Бладимир Маяковский. Могучая фигура великого поэта-агитатора изображена на плакате художника Н. Денисовского [III];

(5) Пламенный советский патриот, вдохновленный певец коммунистической партии, Маяковский отдал „всю свою звонкую силу поэта” борьбе за победу коммунизма [IV];

(6) В «Левом марше» Маяковский занял исходную позицию всего своего творческого пути после Октабря: поэтического глашатая идеи советского патриотизма [II, s. 7];

(7) Поэт-гражданин страстно призывал к революционной бдительности во имя коренных интересов народа и социалистического государства [I].

W tej grupie nominacji rzucają się w oczy zwłaszcza równorzędne zestawienia rzeczownikowe pisane z lącznikiem nоэт-aəumamop, поэт-трибун (vs поэт - трибун эпохи социализма), а zwłaszcza поэт-гражданин, które wskazują na funkcjonowanie w obrębie dyskursu zbitek pojęciowych tworzących stosunkowo utrwalone kategorie. Do najbardziej skostniałych należy chyba zaliczyć zestawie- 
nia поэт-трибун і поэт-гражданин. Oba odwołują się do pojęć okresu republikańskiego Rzymu i zostały spopularyzowane na gruncie rosyjskim na przełomie XVIII i XIX wieku przez autorów i zwolenników nurtu obywatelskiego w poezji ${ }^{4}$. Co ciekawe, te nominacje stawiają Majakowskiego niejako po obu stronach interakcji społecznej jednocześnie. Jako trybun wypowiada się on bowiem w imieniu i po stronnie ludu, zajmując tym samym pozycję nieco wyższą, natomiast jako obywatel jest jego integralną częścią. Trybun (ludowy) to, zgodnie z antycznym rozumieniem pojęcia, ktoś obdarzony pewnym mandatem przez obywateli, kto reprezentuje ich interesy wobec Republiki. W tekstach nowożytnych trybunami patetycznie określano osoby reprezentujące interesy niższych stanów, stające w ich obronie. W słowniku Walerija Mokijenki i Tatiany Nikitiny definicja leksemu трибун została zilustrowana własnie postacią Majakowskiego: „ТРИБУН,а, м. Общественный деятель - выдающийся оратор u публицист. *Трибун революции. Патет. В.В. Маяковский”. Obywatel (гражданин - „Лиц, принадлежащее к населению какого-либо государства, пользущееся всеми правами и исполняющее все обязанности, установленные законамии государства"6 to natomiast, jeśli brać pod uwagę definicję podaną w nawiasie, szeregowy członek tej społeczności.

Zastrzegłem już, że jest tak jednak wówczas, gdy ograniczymy się do przytoczonej definicji leksemu гражданин. Wydaje się jednak, że w przypadku zestawienia поэт-гражданин byłoby to niewłaściwe. Jest tak dlatego, że ta zbitka pojęciowa kształtowała się w rosyjskiej lingwokulturze w warunkach, w których postawa obywatelska była całkowicie nieoczywista, kiedy deklaratywne (bo przecież nie w sensie cywilno-prawnym) bycie obywatelem oznaczało deklarację zaangażowania społeczno-politycznego, a nawet wyzwanie wobec panującego ustroju samodzierżawia7 . Jak zauważa Irina Fan:

4 Na szczególną uwagę zasługują tu, jak się wydaje, dwa wiersze utrwalające koncept poety-obywatela - Гражданин Konstantina Rylejewa i Поэт и гражданин Nikołaja Niekrasowa.

5 В.М. Мокиенко, Т. Г., Никитина, Толковый словарь языка Совдепии, Фолиопресс, Санкт-Петербург 1998, s. 607.

6 Tamże, s. 135

7 Car Paweł I w 1797 roku wydał specjalny ukaz zabraniający używania leksyki związanej z rewolucja, w spisie tym znajdowało się słowo „граждане” (И.Б Фан, Гражданин в контексте города: исторический смысл понятия, „Научный ежегодник Института философии и права Уральского отделения Российской академии наук” 2003, вып. 4, s. 119) 
С этого момента в российском понятии «гражданин», как и во многих других общественно-политических понятиях, можно зафиксировать отрыв от реальности. В нем закрепляется, с одной стороны, идеал - в его качестве выступает европейский (французский citoyen) гражданин, член нации-государства, а с другой - с оглядкой на не до конца осознанную невозможность реализовать этот идеал на русской почве, акцентируется не значение законопослушного гражданина как субъекта конституционного и гражданского права, а значение гражданина, оппозиционно, радикально революционно настроенного по отношению к правительству и государству, культивируется „революционная сознательность”.

Stąd też bierze się trwała asocjacja obywatelskości z postawą nie tyle zaangażowaną, co zaangażowaną w znacznym stopniu, o czym świadczyć mogą przykłady:

Такого приговора я прошу, я ожидаю от вас как защитник, как человек, как гражданин! (Н. И. Холев, Речь в защиту Максименко (1890), NKRJ9),

Семейные основы поруганы, честь затоптана в грязь, порок торжествует, а потому я, как гражданин и честный человек, должен явиться мстителем (А. П. Чехов, Мститель (1887), NKRJ);

Война была народною: в солдате сиял гражданин, и, признаюсь, мне тогда же стало жутко за французов, хотя я всё еще твердо был уверен, что те поколотят немцев (Ф. М. Достоевский, Дневник писателя (1876), NKRJ);

Я знаю, что истинный гражданин, конечно, не затруднится ни перед какою жертвою, но пусть же он согласится со мною, что это жертва очень нелегкая (М. Е. Салтыков-Щедрин, Наша общественная жизнь (18631864), NKRJ);

Без всякой надежды увидеть святую Русь, без всякой мысли о награде, о славе, сей усердный гражданин хотел еще и накануне смерти быть полезным государю, отечеству (Н. М. Карамзин, История государства Российского: Том 9 (1816-1820), NKRJ).

Ta użyteczna asocjacja została zaadaptowana przez dyskurs komunistyczny w ZSRR ${ }^{10}$. Jeszcze w 1982 roku Swietłana Ikonniko-

8 И. Б. Фан, Гражданин в контексте города..., s. 133-134

9 NKRJ - Национальный корпус русского языка, http://www.ruscorpora.ru/.

${ }^{10}$ Oczywiście, nie wyczerpuje to kwestii pragmatycznych możliwości leksemu гражданин. Bywało też i tak, że tę jednostkę wykorzystywano w funkcji sygnału podporządkowania. Jak pisze I. Fan: „Смысловое поле данного концепта в этот период распределяется между двумя полюсами: 1) как мифологема советской идеологии слово стало заключать в себе значение "гражданин СССР - активный, сознательный строитель социализма и коммунизма», «проводник линии ВКП(б) - КПСС»; 2) как термин уголовного права, доминирующего в системе права советского государства, гражданин почти слилось с «преступником», или, во всяком случае, «лицом, подконтрольным государству, тем, кому положено держать перед государством ответ». В среднем же, об- 
wa i Władimir Lisowskij w opracowaniu На пороге гражданской зрелости w następujący sposób określali obywatela ZSRR:

Гражданин СССР - это не просто подданный своей социалистической державы, а ее горячий патриот, глубоко преданный делу партии, делу коммунизма. Это человек большого трудолюбия, общественного темперамента, активный участник строительства нового общества, борец за победу коммунистических идеалов во всех сферах жизни ${ }^{11}$.

$\mathrm{Na}$ rolę Majakowskiego jako twórcy oddanego idei rewolucji wskazują liczne patetyczne nominacje: поэт революции, поэтагитатор, вдохновенный певец коммунистической партии, поэтический глашатай идеи советского патриотизма. Interesujące, że w latach 50. słowa określające działalność w ramach sowieckiego aparatu propagandowego i osoby, które ją uprawiają, takie jak агитатор, агитация, ale też пропагандист, пропаганда nie są jeszcze obarczone negatywnymi konotacjami, wciąż aktualny jest obraz szlachetnego agitatora, który poświęca się głoszeniu idei „nowego", „lepszego" komunistycznego świata. Nominacje noэm революции і вдохновенный певец коммунистической партии współtworzą romantyczną wizję Majakowskiego, a sprawa rewolucji i partii komunistycznej zostaje w ten sposób uduchowiona, staje się kwestią pozaracjonalną (a zatem odporną na krytykę), kwestią porywu serca (oczywiście, szlachetnego), a nie przedmiotem racjonalizacji. Ten rys jest, zresztą, charakterystyczny dla sowieckiego dyskursu ideologicznego, w którym kwestie światopoglądowe należą częściej do domeny emocji niż rozumu, o czym świadczy częste występowanie rzeczowników nazywających uczucia oraz szerokie rozpowszechnienie takich określeń, jak пламенный, страстный, вдохновенный, горячий przy dość niskiej frekwencji przymiotników odwołujących się do sfery racjonalnej, np.:

(8) Со всей силой гнева он пригвождал к позорному столбу троцкистов врагов народа [I];

щем употреблении к эпохе «застоя» термин гражданин приобрел нейтральный, размытый смысл, традиционный для русской истории, - «жителя, лица, принадлежащего государству»" (И. Б. Фан, Гражданин в контексте города..., s. 136-137). Tego typu interpretacja nie wchodzi jednak w grę, gdy mowa o Majakowskim.

${ }^{11}$ Cyt. za: В. В. Маленков, Локальная гражданственность как фактор городского развития, «Теория и практика общественного развития» 2013, $\mathrm{nr} 12$, S. 13 . 
(9) Поэт-гражданин страстно призывал к революционной бдительности во имя коренных интересов народа и социалистического государства [I];

(10) Гордясь освобожденным народом, Маяковский давал страстную отповедь буржуазным клеветникам, разоблачал белоэмигрантские поклепы на советский строй, выысмеивал узколобые буржуазное представление о нашем человеке [I];

(11) Но с самых первых литературных выступлений его вела ненависть к буржуазии... [II, s. 4];

(12) Величайшей заслугой и благороднейшей традицией Маяковского является то, что он [...] с одинаковой любовью писал книги, стихи для толстых журналов и для сатирических изданий [V];

(13) Маяковский всегда был пламенным другом трудящихся Китая [VI];

(14) Страстное слово поэта-трибуна звучит и будет звучать века, приводя в движение сердца миллионов, вдохновляя на труд и на творчество, на самоотверженную защиту отчизны от происков врагов [IV];

(15) В нашем изобразительном искусстве, особенно в скульптуре, были явления родственные пламенной поэзии Маяковского [VII];

(16) На долю деятелей советской литературы и искусства выпало великое счастье быть страстными и горячими пропагандистами новой жизни, ее вдохновленными и пламенными певцами, смелыми и целеустремленными борцами за торжество передовых идей нашего времени [VIII];

(17) Гневно бьет по национализму страстное слово незабываемого Ярослава Галана [IX].

Dość ciekawy jest przykład użycia nominacji поэтический глашатай идеи советского патриотизма. Użycie pojęcia historycznego глашатаŭ również można uznać za element swego rodzaju romantyzacji wizerunku Majakowskiego, próbę nadania mu specyficznej patyny. Doskonale koresponduje to z serią odwołań do etosu rycerskiego, wobec postaci samego Majakowskiego poprzez wykorzystanie historycznej atrybutyki militarnej (боевой горн - patrz niżej), ale i poza kontekstami związanymi z tym akurat poetą, np.:

(18) Тут можно не стесняться в выражениях и орудовать пером, как разящим мечом [X].

Działalność poety-agitatora, piewcy rewolucji, jej herolda charakteryzuje się w badanych tekstach szczególną intensywnością. Głos poety winien być i był głosem mocnym, donośnym i potężnym, np.:

(19) Полной грудью вдохнув революции, молодой Маяковский громовым голосом заговорил об Октябрьской победе [I]

Nie ma tu miejsca na działania o umiarkowanej czy średniej intensywności, jest to działalność emocjonalna, a zatem również rady- 
kalna, doprowadzona do granic. Szczególną rolę w budowaniu tego etosu odegrały czasowniki i imiesłowy oraz związki wyrazowe oznaczające działania o wysokim stopniu brutalności: бичевать, бить, (за)клеймить, казнить, пригвождать к позорному столбу (к газетному листу), пр.:

(20) Это он своей уничтожающей сатирой заклеймил гнилой капиталистический быт Америки и Европы, бичевал ${ }^{12}$ хищническую, империалистическую политику, это он громовым голосом трибуна защищал людей, угнетаемых в капиталистическом мире [XI];

(21) Только это дало такую силу его сатире, бичующей капитализм и буржуазию [VI];

(22) Глубоко обнажая существо капитализма, оно бьет и по сегодняшним врагам мира [XII];

(23) О. Солюс почему-то играет положительного театрального деятеля, когда известно, что Маяковский в этом образе клеймил режиссеров, действующих по принципу: «Чего изволите?» [XIII];

(24) Стихи Маяковского, клеймящие американских трестовских воротилчеловеконенавистников, организаторов новой мировой бойни, хорошо запомнились им [II, s. 16];

(25) В разоблачении этого дельца сатира достигает грозной силы. Она казнит труса и ловкого жулика [XIII];

(26) Со всей силой гнева он пригвождал к позорному столбу троцкистов - врагов народа [I]

(27) Своей железной строкой он пригвождает к газетному листу лицемерных французских парламентариев, которые устраивают доклады о голоде в Поволжье [...] [II, s. 11].

W pewnym związku z tą serią czasowników i konstrukcji czasownikowych, które można umiejscowić w szerszym polu semantycznym „wymiar sprawiedliwości” pozostaje porównanie Majakowskiego do sędziego:

(28) В это время на экране появляется портрет В. В. Маяковского. Как суровый судья взирает он, поэт, на комически поверженного Победоносикова и словно говорит «Нет, не нужны в коммунизме победоносиковы!» [XIII],

choć ich semantyka podpowiadałaby raczej w tym miejscu jednostkę naлач, która jednak z oczywistych powodów nie mogła się pojawić w takim kontekście.

Jedną z podstawowych funkcji sowieckiej literatury było demaskowanie wroga. Standardowym czasownikiem używanym w tek-

${ }^{12}$ A w związku z tym: „Маяковскому нужны были «слова-бичи» для травли всего негодного, мешающего стройке социалистической родины” (II, s. 10). 
stach jej dotyczących jest jednostka разоблачать (разоблачить). $\mathrm{W}$ tekstach dotyczących Majakowskiego występuje ona (lub leksemy powiązane z nią słowotwórczo) dosyć często, np.:

(29) В разоблачении этого дельца сатира достигает грозной силы. Она казнит труса и ловкого жулика [XIII];

(30) Многие его произведения посвящены разоблачению фальшивых людей, явных и скрытых врагов советского общества, отступников разного рода [I];

(31) Гордясь освобожденным народом, Маяковский давал страстную отповедь буржуазным клеветникам, разоблачал белоэмигрантские поклепы на советский строй, выысмеивал узколобое буржуазное представление о нашем человеке [I];

(32) Своей железной строкой он [...] разоблачает военные приготовления заграничных «миротворцев», с великолепным презрением отвечает американским «мистерам», сомневающимся в успехах социалистического строительства (s. 11).

Czasem towarzyszą im przysłówki intensyfikujące, jak na przykład:

(33) Беспощадно разоблачая клеветников, кричавших о том, что социализм будто бы ведет к уравниловке, к «обезличению» человека, Маяковский показал многогранный облик нашего человека, выразил содержательность и богатство характеров советских людей, широту их интересов [I].

Jednak najmocniej w poetykę tekstów o Majakowskim wpisują się metaforyczne odpowiedniki w rodzaju:

(34) Глубоко обнажая существо капитализма, оно бьет и по сегодняшним врагам мира [XII];

(35) Поэт с большой политической зрелостью вскрывал корни уродливых явлений [I],

które wskazują na ostateczny wymiar działalności Majakowskiego.

To, co udało się zdemaskować należy zaś zniszczyć. W badanych tekstach znalazły się dwa czasowniki związane z tą semantyką:

(36) Он выкорчевывал все, что мешало строить новый быт, новую жизнь [I]

(37) Нужно ли говорить о том, как ненавистен был Маяковскому дух низкопоклонства перед буржуазной культурой, как он стремился, говоря словами бессмертной комедии Грибоедова, истребить «нечистый этот дух пустого, рабского, слепого подражания» [II, s. 17]. 
Jedną z form walki ze zdemaskowanym wrogiem, względnie z ujawnionymi zjawiskami negatywnymi, jest satyra. Majakowskiego uważano za wybitnego satyryka, zaś ten rodzaj działalności literackiej w Rosji i ZSRR miał szczególny etos i wiązał się ściśle z walką ideologiczną, np.:

(38) Назвался груздем - полезай в кузов. Присвоил себе роль сатиры - кусай, язви, жги, да так, чтобы многие тебя боялись, а смеялись все! [V].

Majakowski w optyce badanych tekstów realizuje ten etos w pełnej rozciągłości, ponieważ nie tylko wyśmiewa, np.:

(39) Гордясь освобожденным народом, Маяковский давал страстную отповедь буржуазным клеветникам, разоблачал белоэмигрантские поклепы на советский строй, выысмеивал узколобое буржуазное представление о нашем человеке [I],

ale wręcz „pastwi się” nad wrogiem lub tymi, którzy nie są wystarczająco zaangażowani w walkę z nim, np.:

(40) Подписи к окнам Роста, которые делал Маяковский, проникнуты неистойчивой верой в победу, презрением к трусам и шептунам, злой издевкой по адресу врага [II, s. 9]

(41) Маяковский беспощадно издевалса над теми поэтами и писателями, которые, под прикрытием работы «на вечность», уходили от современности... [II, s. 3]

Władimir Majakowski jest w badanych tekstach uosobieniem wartości, które wpajano radzieckim literatom. Po pierwsze mieli oni służyć określonej ideologii (поэт революции, поэт агитатор, певец, глашатай) bądź narodowi (поэт-трибун). Jedną z jednostek leksykalnych eksplicytnie wyrażających tę kategorię, którą odnajdujemy w tekście o Majakowskim, jest czasownik служuть:

(42) Поэзия Маяковского служит великому делу пропаганды идей социализма, идей мира и подлинной демократии, служит делу борьбы за коммунизм [XIV].

W tekstach sowieckiego dyskursu ideologicznego jednostki служить, служба, задача, а zwłaszcza долг nie sygnalizują jednak jedynie relacji podporządkowania czy, jak można by wnioskować z przytoczonego przykładu, instrumentalizacji, ale zinternalizowaną postawę samych autorów bądź znaczącą rolę ich dzieł ${ }^{13}$. Idealny lite-

${ }^{13}$ Szerzej na ten temat piszę w artykule Relacje władza - artysta $w$ sowieckim ideologicznym subdyskursie o kulturze w latach 1953-1957, w: A. Klimkiewicz, 
rat, jakim miał być Majakowski, miał się tej służbie oddawać z pełnym zaangażowaniem, działać radykalnie, bezpardonowo. Przeanalizowane jednostki tworzą właśnie taki obraz poety, który miał być wzorem dla literatów w okresie sporu o kształt radzieckiej kultury we wczesnym okresie po śmierci Stalina.

Spór, o którym mowa, był pośrednio konceptualizowany jako wojna, Majakowski zaś stał się chyba najbardziej „zmilitaryzowanym” twórcą w całej historii kultury radzieckiej. O jego twórczości pisano m.in.:

(43) Стихи певца социалистической революции, подобные „бомбе и знамени”, открыли перед передовыми поэтами Китая новые пути в их творчестве [VI].

Jest to cytat z wiersza Majakowskiego („И песня, и стих это бомба и знамя, и голос певца подымает класс", Господин „народный артист”). W twórczości poety topika wojenna zajmowała istotne miejsce, jak choćby w wierszu „Марксизм - оружие, огнестрельный метод. Применяй умеючи метод этот!”:

\author{
Штыками \\ двух столетий стык \\ закрепляет \\ рабочая рать. \\ А некоторые \\ употребляют штык, \\ чтоб им \\ в зубах ковырять. \\ Все хорошо: \\ поэт поет, \\ критик \\ занимается критикой. \\ У стихотворца - \\ корытце свое, \\ у критика - \\ свое корытико. \\ Но есть \\ не имеющие ничего, \\ окромя \\ красивого почерка. \\ А лезут \\ в книгу,
}

Ż. Sładkiewicz (red.), Perswazja językowa $w$ różnych dyskursach, t. 1, Wydawnictwo UG, Gdańsk 2017, s. 187-203. 
хваля

и громя

из пушки

критического очерка.

O tym, że postać Majakowskiego wiązano z etosem walki, świadczy cytat z „Literaturnoj gazety”, który przytacza Iwan Bunin:

В связи с недавней двадцатилетней годовщиной его самоубийства московская „Литературная газета” заявила, что „имя Маяковского воплотилось в пароходы, школы, танки, улицы, театры и другие долгие дела. Десять пароходов 'Владимир Маяковский' плавают по морям и рекам. 'Владимир Маяковский’ было начерчено на броне трех танков. Один из них дошел до Берлина, до самого рейхстага. Штурмовик 'Владимир Маяковский’ разил врага с воздуха. Подводная лодка ‘Владимир Маяковский’ топила корабли в Балтике" ${ }^{14}$.

Metafora militarna należała do ulubionych chwytów mobilizujących sowieckiej propagandy, w tym w obszarze kultury. Natalia Tabałowa zauważa, że

Милитарная метафора навязывает обществу конфронтационные стереотипы решения проблем, ограничивает поиск альтернатив в социальном развитии и решении конкретных проблем ${ }^{15}$.

Militaryzacja dyskursu jest tym, na co zwracał uwagę Afanasij Seliszczew już w 1928 roku $^{16}$. Szerokie występowanie pojęć z zakresu wojny i wojskowości było uzasadnione tym, że badany dyskurs rzeczywiście kształtował się w warunkach walki - najpierw z władzą carską, potem w okolicznościach trwającej wojny domowej, jednak po niespełna trzydziestu latach Andriej i Tatiana Fiesienkowie pisali:

Пришли будни мирного строительства, казалось бы не нуждающегося в подхлестывании военными фразами, но эти будни были настолько серы и бесперспективны, а усилия и жертвенность настолько не находили себе

${ }^{14}$ И.А. Бунин, Полное собрание сочинений в XIII томах, т. 9, Издательство Воскресенье, Москва 2006, s. 161.

${ }^{15}$ Н.Г. Табалова, Социальные стереотипы как форма категоризации действительности в лингвистическом, психологическом и социологическом аспектах // «Язык, сознание, коммуникация» 2003, вып. 23, s. 57, por. Э. В. Будаев, Военная метафорика в дискурсе СМИ, „Аcta Linguistica” 2008, vol. 2, nr 1, s. 29-30.

${ }^{16}$ А.М. Селищев, Язык революционной эпохи. Из наблюдений над русским языком, Издательство УРСС, Москва 2003, s. 85-96. 
оправдания в неизменившейся к лучшему жизни, что власти считали целесообразным сохранить «боевой» язык, зовущий массы ко все новым напряжениям, ко все новым самопожертвованиям ${ }^{17}$.

Po kolejnych ponad trzydziestu latach (francuski tekst opublikowano w 1987 roku) Françoise Thom napisze:

Staje się więc jasne, że wiele terminów stosowanych w drewnianym języku zaczerpniętych jest z repertuaru militarnego; symbolika wojenna rozciąga się nawet na dziedziny tradycyjnie bukoliczne - gdy mowa o dojeniu krów czy o kopaniu ziemniaków, słyszy się w kółko tylko o frontach, bataliach, atakach, stawianiu oporu, braniu szturmem, strategii i taktyce itd. Nawet pokój staje się obiektem zaciekłej walki. Czytając prasę ma się wrażenie, że całe społeczeństwo jest w stanie ciągłej mobilizacji ${ }^{18}$.

Jest to zatem pewna konstanta, której ucieleśnieniem był poeta-wojownik Władimir Majakowski. W tekstach mu poświęconych znajdujemy bowiem liczne przykłady leksyki militarnej bądź zaczerpniętej z dyskursu konfrontacji: бить, вооружить, оттачивать оружие, давать прицел кому-л., воевать, бороться, воинствующе, борясь, боевой, боръба, борец, боевой горн. Celem tych użyć było kreowaniewizerunkutwórcy-wojownika, którymiałstaćsięwzorem do naśladowania dla środowisk tzw. inteligencji twórczej w okresie sporu o kształt życia kulturalnego ZSRR po śmierci Stalina. Oto przykłady:

(44) В этом отношении особенно ярко стихотворение «Явление Христа». Глубоко обнажая существо капитализма, оно бъет и по сегодняшним врагам мира [XII];

(45) Величайшей заслугой и благороднейшей традицией Маяковского является то, что он не признавал габаритов для своего боевого творчества ... [V];

(46) Он воинствующе выступал против поэзии серой, тусклой, безличной [I];

(47) Вторгаясь в жизнь, борясь за то, чтобы приблизить будущее, Маяковский выработал свой художественный метод ... [II, s. 20];

(48) Маяковский хотел вооружить своим стихом рабочий класс в его великой борьбе [II, s. 23];

${ }_{17}$ А. и Т. Фесенко, Русский язык при советах, Rausen Bros, Нью-Йорк 1955, S. 139.

${ }^{18}$ F. Thom, Drewniany język, przeł. I. Bielicka, CDN, Warszawa 1990, s. 17; por. m.in. А.П. Чудинов, Россия вметафорическомзеркале: когнитивноеисследование политической метафоры (1991-20оо), Издательство УрГПУ, Екатеринбург 2001, s. 105; Д. Вайс, Сталинский и национал-социалистический дискурсы пропаганды: сравнение в первом приближении, «Политическая лингвистика» 2007, $\mathrm{nr} 1$ 3(23), s. 40. 
(49) Он был пламенным борцом за мир, за счастье народов [I];

(50) Маяковский - участник революции. Только это позволило ему воспринять каждый вздох революции и „всю свою звонкую силу поэта” превратить в боевой горн, зовущий народ вперед [VI];

(51) Его поэзия оттачивает оружие поэтов, дает им прицел [XV];

(52) Поэзия Маяковского идет и будет идти в боевом строю совет-ского народа, созидающего коммунизм [IV].

Ten „wojowniczy” wizerunek poety, który podawano jako wzorzec dla twórców, był niezwykle potrzebny i użyteczny w okresie przesilenia, w czasie, gdy trwała walka (z punktu widzenia luminarzy okresu stalinowskiego) o utrzymanie dawnego paradygmatu w kulturze lub przynajmniej o „ograniczenie strat”.

Jednym z argumentów strony „atakującej” pozycje działaczy kulturalnych epoki stalinowskiej był fakt, że życie kulturalne i artystyczne Związku Sowieckiego uległo skostnieniu, zabetonowaniu. Wówczas postać Majakowskiego również okazała się użyteczna, ponieważ był on sztandarowym poetą epoki stalinowskiej, a przecież nikt choć trochę zaznajomiony z jego twórczością nie mógł twierdzić, że brakowało w niej nowatorstwa. Staje się więc Majakowski swego rodzaju tarczą służącą obronie „starego” przed tego rodzaju zarzutami. Jako „nowatora” pozycjonowano go po stronie stalinowskiego paradygmatu w kulturze. W narracjach tego typu najbardziej oczywistymi jednostkami wyrażającymi tę kategorię są rzeczownik новатор i przymiotnik новаторский, np.:

(53) Маяковский продолжал передовые традиции классической русской литературы, творчески их обогащал и развивал, являясь подлинным новатором, пролагателем новых путей в искусстве [IV];

(54) У истоков советской литературы стоят два таких гиганта, как М. Горький и В. Маяковский, творчество которых, глубоко новаторское в своей сущности, явилось вместе с тем блисталельным продолжением вдохновенного труда предшествовавших им писателей-классиков [XVI];

(55) Не случайно, что наиболее смелые новаторские поиски поэтов братских литератур идут под знаком освоения традиции «лучшего, талантливейшего поэта нашей советской эпохи» - Владимира Маяковского [XVII].

Miało to na celu wywołanie wrażenia, że paradygmat ów nie wyczerpał jeszcze swojego potencjału i że ma on jeszcze „przyszłość”. Majakowski był tą postacią, która winna była tę przyszłość wskazywać:

(56) Маяковский зовет зрителей в будущее и во имя этого быдущего высмеивает тех, кто несет в себе пережитки прошлого [XIII]. 
Podkreślmy raz jeszcze, że dwuprocentowy udział w całej liczbie publikowanych przez „Prawdę” tekstów o kulturze, który przypada Majakowskiemu, to bardzo dużo. Odsetek ten wynika właśnie z faktu, że postać ta „obsługiwała” jednocześnie kilka pól tematycznych, na których „stare” stawiało opór „nowemu”. Majakowski był bowiem ucieleśnieniem specyficznie pojmowanej „obywatelskości” i zaangażowania, które przeciwstawiano „bezideowości” kierunków spoza nurtu socjalistycznego realizmu, był uosobieniem samej walki, i wreszcie - uosobionym zaprzeczeniem tezy o skostnieniu socjalistycznego realizmu.

\section{REFERENCES}

Budayev, Eduard. "Voyennaya metaforika v diskurse SMI." 29-36. Acta Linguistica 2008, vol. 2, no. 1 [Будаев, Эдуард. "Военная метафорика в дискурсе СМИ.” 29-36. Acta Linguistica 2008, vol. 2, no. 1].

Bunin, Ivan. Polnoye sobraniye sochineniy. Vol 9. Moskva: Izdatel'stvo Voskresen’ye 2006. Moskva, 2006 [Бунин, Иван. Полное собрание сочинений. Т. 9. Москва: Издательство Воскресенье, 2006.].

Bykov, Dmitriy. Mayakovskiy. Tragediya-buff v shesti deystviyakh. Moskva: Izdatel'stvo Molodaya gvardiya, 2016 [Быков, Дмитрий. Маяковский. Трагедиябуфф в шести действиях. Москва: Издательство Молодая гвардия, 2016].

Chudinov, Anatoliy. Rossiya $v$ metaforicheskom zerkale: kognitivnoye issledovaniye politicheskoy metafory (1991-200o). Moskva: Izdatel'stvo UrGPU, 2001 [Чудинов, Анатолий. Россия в метафорическом зеркале: когнитивное исследование политической метафоры (1991-20оо). Екатеринбург: Издательство УрГПУ, 2001].

Fan, Irina. "Grazhdanin v kontekste goroda: istoricheskiy smyslponyatiya." 112-137. Nauchnyy yezhegodnik Instituta filosofii i prava Ural'skogo otdeleniya Rossiyskoy·akademii nauk 2003, vyp. 4 [Фан, Ирина. "Гражданин в контексте города: исторический смысл понятия." 112-137. Научный ежегодник Института философии и права Уральского отделения Российской академии наук 2003, вып. 4].

Fesenko, Andrey, Фесенко Tat'yana. Russkiy yazyk pri sovetakh. N'yu-York: Rausen Bros, 1955 [Фесенко, Андрей, Фесенко, Татьяна. Русский язык при советах. Нью-Йорк: Rausen Bros, 1955].

Malenkov, Vyacheslav. "Lokal'naya grazhdanstvennost' kak faktor gorodskogo razvitiya." 12-18. Teoriya i praktika obshchestvennogo razvitiya 2013, no. 2 [Маленков, Вячеслав. “Локальная гражданственность как фактор городского развития.” 12-18. Теория и практика общественного развития 2013, no. 2].

Mokiyenko, Valeriy, Nikitina, Tat'yana. Tolkovyy slovar' yazyka Sovdepii, Sankt-Peterburg: Folio-press, 1998 [Мокиенко, Валерий, Никитина, Татьяна. Толковый словарь языка Совдепии. Санкт-Петербург: Фолио-пресс, 1998].

Pertsov, Viktor. "Velikiy poet sovetskoy epokhi." Mayakovskiy, Vladimir. Izbrannyye proizvedeniya. Vol. I. 3-36. Ed. Pertsov, Viktor. Moskva: Gosudarstvennoye 
izdatel'stvo khudozhestvennoy literatury, 1953 [Перцов, Виктор, "Великий поэт советской эпохи.” Маяковский, Владимир. Избранные произведения. T. I. 3-36. Сост. Перцов, Владимир. Москва: Государственное издательство художественной литературы, 1953].

Selishchev, Afanasiy. Yazyk revolyutsionnoy epokhi. Iz nablyudeniy nad russkim yazykom. Moskva: Izdatel'stvo URSS, 2003 [Селищев, Афанасий. Язык революционной эпохи. Из наблюдений над русским языком. Москва: Издательство УРСС, 2003].

Stalin, Iosif. Sochineniya. Vol. 18. Tver': Informatsionno-izdatel'skiy tsentr «Soyuz», 2006 [Сталин, Иосиф. Сочинения. Т. 18. Тверь: Информационноиздательский центр «Союз», 2006].

Tabalova, Natal'ya. "Sotsial'nyye stereotipy kak forma kategorizatsii deystvitel'nosti v lingvisticheskom, psikhologicheskom i sotsiologicheskom aspektakh." 52-57. Yazyk, soznaniye, kommunikatsiya 2003, vyp. 23 [Табалова, Наталья. "Социальные стереотипы как форма категоризации действительности в лингвистическом, психологическом и социологическом аспектах.” 52-57. Язык, сознание, коммуникация 2003, вып. 23].

Thom, Françoise. Drewniany język. Transl. ???. Warszawa: CDN, 1990.

Vays, Daniel'. "Stalinskiy i natsional-sotsialisticheskiydiskursy propagandy: sravneniye v pervom priblizhenii.” 34-6o. Politicheskaya lingvistika 2007, no. 1 3(23) [Вайс, Даниэль. "Сталинский и национал-социалистический дискурсы пропаганды: сравнение в первом приближении.” 34-6о. Политическая лингвистика 2007, no. $13(23)]$.

Zemszał, Piotr. "Relacje władza-artysta w sowieckim ideologicznym subdyskursie o kulturze w latach 1953-1957." Perswazja językowa w różnych dyskursach. Vol. 1. 187-203. Ed. Klimkiewicz, Aleksandra, Sładkiewicz Żanna. Gdańsk: Wydawnictwo Uniwersytetu Gdańskiego, 2017.

\section{ŹRÓDŁA CYTATÓW}

I. М. Луконин, Великий певец советского народа» (к 6о-летию со дня рождения В. В. Маяковского), „Правда”, 19 июля 1953.

II. В.О. Перцов, Великий поэт советской эпохи, w: В.В. Маяковский, Избранные произведения, Государственное издательство художественной литературы, Москва 1953, s. 3-36.

III. Б. Ефимов, Испытанное оружие, „Правда”, 24 июня 1957.

IV. За марксистское освещение творчества В. Маяковского, „Правда”, 7 марта 1953.

V. Д. Заславский, О сатирических журналах, „Правда”, 5 сентября 1956.

VI. Юань Шуй-По (китайский поэт, около дня 6о-летия со дня рождения Маяковского), Благородный пример для поэтов Китая, „Правда”, 19 июля 1953.

VII. Высокое призвание советского художника, „Правда”, 9 марта 1957.

VIII. Высокое призвание деятелей литературы и искусства, „Правда”, 1 сентября 1957. 


\section{WIZERUNEK WŁADIMIRA MAJAKOWSKIEGO...}

IX. М. Бажан, Накануне съезда писателей советской Украины, „Правда”, 2 сентября 1954.

Х. П. Кузнецов, В. Куприн, На новые высоты (Третий съезд советских писателей Казахстана), „Правда”, 17 сентября 1954.

XI. С. Щипаев, Поэзии - могучие крылья. Заметки поэта, „Правда”, 19 сентября 1954.

XII. А. Абрамов, Боевая, нестареющаяся поэзия (о книге „Маяковский об Америке”), около 6о-летия дня рождения Маяковского, „Правда”, 18 июля 1953.

XIII. В. Фролов, Сатира Маяковского на сцене (о спектакле „Баня” в Московском театре сатиры, „Правда”, 2 марта 1954.

XIV. C. Перов, За научное издание сочинений В. Маяковского, „Правда”, 14 апреля 1953.

XV. Л. Стоянов, Слово звучащее на весь мир, „Правда”, 15 декабря 1954.

XVI. А. Сурков, Под знаменем социалистического реализма, (Навстречу Второму Всесоюзному съезду писателей), „Правда”, 25 мая 1954.

XVII. А. Сурков, „Состояние и задачи советской литературы (Второй всесоюзный съезд сов. писателей), „Правда”, 16 декабря 1954. 